Блаженкова Ю. П.

ИНТЕГРАТИВНОСТЬ КАК ПОТЕНЦИАЛ РАЗВИТИЯ БИБЛИОТЕКИ В ХУДОЖЕСТВЕННОМ МУЗЕЕ

(НА ПРИМЕРЕ БИБЛИОТЕКИ ПРИМОРСКОЙ ГОСУДАРСТВЕННОЙ КАРТИННОЙ ГАЛЕРЕИ)

Блаженкова Ю. П.

Yu. P. Blazhenkova

ИНТЕГРАТИВНОСТЬ КАК ПОТЕНЦИАЛ РАЗВИТИЯ БИБЛИОТЕКИ

В ХУДОЖЕСТВЕННОМ МУЗЕЕ (НА ПРИМЕРЕ БИБЛИОТЕКИ

ПРИМОРСКОЙ ГОСУДАРСТВЕННОЙ КАРТИННОЙ ГАЛЕРЕИ)

\title{
INTEGRATION AS A POTENTIAL OF LIBRARY DEVELOPMENT \\ IN AN ART MUSEUM (ON THE EXAMPLE OF THE LIBRARY \\ OF THE PRIMORSKAYA STATE PICTURE GALLERY)
}

Блаженкова Юлия Павловна - заведующий научно-просветительским отделом КГАУК «Приморская государственная картинная галерея» (Россия, Владивосток). E-mail: lib_primgallery@mail.ru.

Ms. Yuliya P. Blazhenkova - head of the scientific and educational department of the Primorskaya State Picture Gallery (Russia, Vladivostok). E-mail: lib_primgallery@mail.ru.

Аннотация. Статья посвящена проблеме интеграционного развития библиотеки в художественном музее. В центре внимания - значение литературного творчества русских живописцев в процессе создания новых форм коммуникации в выставочном пространстве картинной галереи.

Summary. The article is devoted to the problem of the library's integration development in an art museum. In the center of attention we observe the importance of literary creativity of Russian painters in the process of creating new forms of communication in the exhibition space of the picture gallery.

Ключевые слова: музей, картинная галерея, библиотека, искусство, культура, просветительская деятельность, наука, художники, писатели.

Key words: museum, art gallery, library, art, culture, enlightenment, science, artists, writers.

УДК 069:01/069:002

Интеграционное развитие музейных библиотек возможно выделить в отдельную область исследований как в теоретическом, так и прикладном аспектах. Интересным материалом для изучения является работа библиотеки Приморской государственной картинной галереи. Одной из задач деятельности библиотеки музея становится не только выполнение мемориальной функции, но и организация новой продуктивной коммуникации с посетителями. Музейный библиотечный фонд обнаруживает огромный потенциал, который можно использовать, чтобы помочь зрителю разобраться в образных значениях печатных изданий или произведений искусства, понять идею выставки или творчество конкретного художника.

В данной статье предметом исследования стал способ освоения музейными библиотекарями книжного фонда в культурологическом и искусствоведческом контекстах, что дало возможность сблизить произведения живописи и литературы в коммуникационном пространстве музея.

В деятельности музея можно выделить различные формы работы, которые по-разному организуют коммуникативный процесс: книжные выставки, адаптированные для различных групп населения; фольклорные, литературные, исторические праздники; лекции, беседы и консультации музейным специалистам; научное исследование.

Зачастую посетители музейной библиотеки обращаются к сотрудникам не только с традиционными вопросами, касающимися автора, названия, года издания книги, но и со сложными вопросами о творчестве того или иного художника, в том числе в области их самовыражения не только в области живописи, но и в литературном творчестве. Достаточно часто сотрудникам музейной библиотеки необходимы знания из смежных с искусствоведением наук, умения интегрировать эти знания в единую картину мира эпохи, стиля, творчества конкретного художника. 


\section{Ученые записки \\ №

Одним из значимых разделов книжного фонда библиотеки Приморской государственной картинной галереи является раздел «Искусство». В нем находятся книжные издания разного профиля, например: книги о творчестве художников, критические статьи, альбомы с репродукциями картин, биографические данные и многие другие. В него также входит еще одна категория книжных изданий - книги, написанные лично художниками о собственном творчестве, мемуары, книги о художниках-современниках. Из практики работы можно утверждать, что спрос на данную литературу невысок, читатели относят такие издания к художественной литературе, которая сегодня востребована в меньшей степени, нежели нон-фикшн, или научная литература. Тем не менее в современном музейном библиотечном фонде достаточно полно представлены издания, содержащие сведения, дополняющие восприятие произведения искусства знанием об особенностях творческого процесса живописцев и графиков: мемуары, переписка с друзьями и близкими, впечатления, полученные в странствиях, авторская философии искусства и творчества.

Что дают зрителю эти источники, кроме понимания одаренности автора и в области живописи, и в области литературы, свидетельствующие о значительном творческом потенциале художника? Прежде, чем ответить на данный вопрос, необходимо понять, каковы предпосылки стремления художников к самореализации на литературном поприще, какова цель их писательской деятельности.

Многие русские и западноевропейские художники разных веков, взяв перо и открыв в себе литературный талант, писали интереснейшие произведения: беллетристику, мемуары, работы в критическом и эпистолярном жанре, рассказы о себе, своем творчестве, современниках, событиях художественной жизни, встречах с интересными людьми, свои наблюдения и размышления. К сожалению, не все литературное наследие художников было сохранено и опубликовано, но дошедшие до нас источники производят сильное впечатление особым эмоциональным настроением, многообразием интерпретаций событий и текстов, положительно воздействуют на эстетические взгляды читателей.

Рассмотрим творчество художников, художественные произведения которых и написанные ими книги находятся в фондовой коллекции Приморской государственной картинной галереи и в библиотеке, и коснемся других известных художников-писателей, поставив акценты на важности общей научной и культурной составляющей.

В составе книжного фонда по искусству произведения известных русских художников второй половины XIX в., таких как: Илья Репин («Далекое близкое», «Бурлаки на Волге», «Воспоминания и шедевры»); Константин Коровин («К. Коровин вспоминает», «Моя жизнь», «То было давно, там, в России»); Михаил Нестеров («Давние дни»; «Письма дочери; «О пережитом (18621917)»), Игорь Грабарь («Петербургская архитектура в XVIII и XIX веках»; «История русского искусства в 6 томах»), оставивших ярчайший след в истории отечественного искусства. Для поклонников их творчества, искусствоведов, культурологов оказалась исключительно важной новая грань творчества мастеров живописи и графики - их талант прекрасных рассказчиков и писателей. Например, русский советский поэт Корней Чуковский, написавший о Репине немало, говорил: «...у Репина было два дарования, и одно - по своим богатым возможностям - было не ниже другого» [5]. Почитатели творчества художника Коровина, познакомившись с его литературным творчеством, находились в восхищении от легкого, душевного и точного языка автора; сегодня его мемуары считаются одними из лучших в литературной практике отечественных мастеров живописи на рубеже XIX-XX вв. Столь же интересна и переписка художника; по свидетельству В. Д. Поленова, письма К. Коровина были «ужасно интересны и талантливы» [4]. Такие тексты весьма ценны на сегодняшний день, они раскрывают эстетический психологизм автора, который позволяет по-новому взглянуть на живописные произведения.

Именно эпистолярный жанр стал наиболее актуальным и популярным жанром, в котором проявлялся литературный талант мастеров кисти. Письма и воспоминания художников позволяли им выразить свои мысли, чувства, эмоции, отношение к тем или иным событиям. Благодаря таким литературным источникам до нас дошли уникальные знания об истории культуры и политической обстановке в стране. К наиболее значимым источникам можно отнести воспоминания художни- 
Блаженкова Ю. П.

ИНТЕГРАТИВНОСТЬ КАК ПОТЕНЦИАЛ РАЗВИТИЯ БИБЛИОТЕКИ В ХУДОЖЕСТВЕННОМ МУЗЕЕ

(НА ПРИМЕРЕ БИБЛИОТЕКИ ПРИМОРСКОЙ ГОСУДАРСТВЕННОЙ КАРТИННОЙ ГАЛЕРЕИ)

ков: Ф. И. Иордана (1800-1883), А. Я. Головина (1863-1930), А. П. Остроумовой-Лебедевой (18711955), Я. Д. Минченкова (1871-1938), Л. С. Бакста (1866-1924), представленные и в фондах библиотеки Приморской государственной картинной галереи. Ценность этих свидетельств трудно недооценить, например: Лев Бакст, друживший с Серовым, охотно рассказывал о совместных путешествиях по Греции (1907); о физической достоверности его воспоминаний писал И. Бунин: «...все видишь, все обоняешь, все осязаешь» [4].

Отметим, что в фонде редкой книги в библиотеке Галереи имеются не только книги, но и журналы, к примеру «Мир искусства» 1898-1924 гг. Неискушенный зритель может «вживую» познакомиться с русской художественной жизнью конца XIX - начала XX вв., со статьями и заметками, а также иллюстрациями художников А. Н. Бенуа, И. Э. Грабаря, В. В. Кандинского и многих других членов одноименного творческого объединения «Мир искусства». Литературное творчество русских художников А. Г. Венецианова (1780-1847), И.Н. Крамского (1837-1887), М. М. Антокольского (1843-1902), В. Д. Поленова (1844-1927), М.В. Нестерова (1862-1942); В. А. Серова (1865-1911), Б. М. Кустодиева (1878-1927) и многих других отличает тонкость восприятия, передача эмоций, воплощенных в интереснейшую словесную форму, легко читаемую и запоминающуюся историю. Интересными писателями, наделенными очевидными литературными способностями, зарекомендовали себя художники В. Г. Перов (1833-1882), В. В. Верещагин (1842-1904), И. Я. Гинцбург (1933-1963), П. А. Нилус (1869-1943); талантливыми в двух ипостасях, по мнению современников, показали себя А. Н. Бенуа (1870-1960) и И. Э. Грабарь (1871-1960). Значительный писательский вклад, включающий в себя мемуары, критические очерки, эпистолярные источники, освещающие важные подробности отечественной и зарубежной истории искусств, содержащие богатейший фактический материал, является богатейшей ресурсной базой для работы музейного библиотекаря, способствуя интеграционному развитию деятельности библиотеки; необходимость работы с назваными ресурсами книжного фонда неоспорима.

Российский искусствовед Екатерина Бобринская, говоря о книге В. В. Кандинского «Избранные труды по теории искусства», отмечает, что «слово художника в новом искусстве оказывается не вторичным сопровождающим материалом, но часто важнейшим инструментом для проникновения в сущность его творчества» [1]. Но значение теоретических сочинений Кандинского не ограничивается рамками его собственного творчества. Они оказали серьезное влияние на самый широкий круг деятелей русской и европейской культуры. Блестящая и универсальная эрудиция автора в области музыки, психологии, философии превращает его тексты не просто в размышления художника о своей профессиональной деятельности, но переводит их в синтетические концепции новой культуры. Впечатления, полученные во время этнографических путешествий, сам Кандинский считал важными импульсами в его поисках нового языка искусства; его живописные работы будут точнее и полнее восприняты зрителем в контексте знакомства с путевыми заметками.

Искал себя в литературе и отец русского футуризма, художник Давид Бурлюк, во время своего пребывания в Америке в 1920-х гг. получивший предложение от владельца одного из японских издательств совместно с художником и теоретиком искусства Киноситой написать книгу об этом художественном направлении. В результате такого сотрудничества в 1923 г. в Японии вышел теоретический труд под названием «Что такое футуризм? Ответ» [3], хотя на практике Бурлюк ответил на этот вопрос японцев еще во время своего пребывания в Японии своими выставками.

Советский график В. А. Фаворский на страницах своей книги повествует, что «...всю свою жизнь, от юности и до старости, был страстным искателем новых путей в искусстве, старался выяснить глубокие основы явлений природы и человеческой жизни и найти для них выражения современный художественный язык» [8]. Разносторонность Фаворского - это не метания нетерпеливого человека. Это желание высказать правду о природе в разных материалах, любовь к природе и этим материалам.

Сегодня художники так же, как и сто лет назад, испытывают потребность писать. В январе 2017 г. в фонд библиотеки галереи поступила книга дальневосточного художника-живописца В. Н. Старовойтова (р. 1945). В автобиографической книге, сборнике мемуарной прозы «Пятый живорождённый», как отметил сам автор, «документальность повествования органично сочетается 


\section{Ученые записки \\ Комсомольского-на-Амуре государственного технического университета

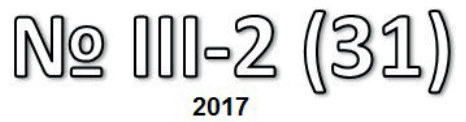

с философскими размышлениями о природе творчества, фантазией и юмором, а также многочисленными воспоминаниями о начале советского Сахалина в 40-50-е гг. прошлого века и немногих поначалу обитателях острова, к коим относится и семья мастера» [2]. Комментарий автора подтвердил актуальность литературной деятельности для современных художников.

Американский теоретик искусства Дуглас Кримп, уважаемый и много цитируемый, в 1981 г. напечатал в журнале Artforum эссе «Конец живописи» [7]. «Речь в нем шла не о том, что живопись кончилась как техника: просто некоторые живописцы стали мигрировать в сторону поиска новых путей репрезентативности. С одной стороны, мир искусства служит как бы приложением к Искусству» [6], - продолжает его мысль российский писатель, арт-критик, искусствовед Леонид Лернер, а известный американский арт-критик и философ Артур Данто в своих трудах высказывается: «Искусство нуждается в чем-то таком, чего глаз не сможет обнаружить, - в атмосфере художественной теории, в знании истории искусства» [6].

Другими словами, произведения искусства, которые бережно хранит художественный музей, нуждаются не только в реставрации, экспонировании, изучении, но и в результатах работы музейной библиотеки, создании широкого культурного контекста, позволяющего зрителю более полно представить мировоззрение художника, его эстетические задачи, идеи, воплощенные в живописном полотне.

\section{ЛИТЕРАТУРА}

1. Бобринская, Е. А. Рецензии / Е. А. Бобринская // Артхроника. - 2010. - № 6. - С. 140.

2. Во Владивостоке прошла творческая встреча с Владимиром Старовойтовым [Электронный ресурс]. Режим доступа: $\mathrm{http}: / /$ novostivl.ru/msg/22811.htm (дата обращения 21.06.2017).

3. Евдаев, Норнберг. Давид Бурлюк в Японии / Норнберг Евдаев // Искусство. - 2007. - № 1. - С. 76-81.

4. Константин, К. А. Моя жизнь / К. А. Константин. - М.: Азбука, 2012. -284 с.

5. Чуковский, Корней. Репин как писатель / Корней Чуковский // Репин И. Далекое близкое [Электронный pecypc]. - Режим доступа: http://royallib.com/read/repin_ilya/dalyokoe_blizkoe.html\#0 (дата обращения 21.06.2017).

6. Лернер, Л. О. От редакции / Л. О. Лернер // Искусство. - 2010. - № 5-6. - С. 9.

7. Мир искусства. Об искусстве [Электронный ресурс]. - Режим доступа: http://wiki.ru/sites/iskusstvo/idarticles-434751.html (дата обращения 21.06.2017).

8. Фаворский, В. А. Литературно-теоретическое наследие / В. А. Фаворский. - М.: Советский художник, 1988. -456 c. 